Article

\title{
Treatment of WASTEWATER from the Tannery Industry in a Constructed Wetland Planted with Phragmites australis
}

\author{
Amalia García-Valero *, Silvia Martínez-Martínez, Ángel Faz, Martire Angélica Terrero, \\ María Ángeles Muñoz, María Dolores Gómez-López and José A. Acosta \\ Sustainable Use, Management and Reclamation of Soil and Water Research Group, Universidad Politécnica de \\ Cartagena, Paseo Alfonso XIII 48, 30203 Cartagena, Spain; smartinez@upct.es (S.M.-M.); afaz@upct.es (Á.F.); \\ aterrero@upct.es (M.A.T.); cons_angeles24@gmail.com (M.Á.M.); mdgomez@upct.es (M.D.G.-L.); \\ jacosta@upct.es (J.A.A.) \\ * Correspondence: amalia.garcia@upct.es
}

Received: 13 January 2020; Accepted: 22 January 2020; Published: 26 January 2020

check for updates

\begin{abstract}
Constructed wetlands (CWs) can remove a high amount of pollutants from wastewater, and therefore play an important role in water purification. In this study, a pilot system to improve the traditional treatment of industrial wastewater from the tannery industry was tested. The main objective of this research was to remove nitrogen, phosphorus, boron, and chromium from a tannery's industrial wastewater using a horizontal subsurface flow constructed wetland (HSSFCW) formed from three cells, planted with Phragmites australis and operated in batch mode as an ecofriendly system. P. australis was selected due to its ability to adapt to climatic conditions, its wetland and management characteristics, and its high capacity for pollutant absorption. The concentrations of total Kjeldahl nitrogen (TKN), total phosphorus (TP), boron (B), and chromium (Cr) were analyzed in both wastewater and purified water, and the removal efficiencies were calculated. In addition, both the absorption capacity of P. australis in the aerial and root parts and the adsorption capacity of substrates (gravel and washed sand) were analyzed. Results showed that the concentrations of TP and $\mathrm{Cr}$ decreased in the wastewater at both hydraulic retention times (HRTs) tested ( 3 and 7 days), with 3 days being the most effective, showing removal efficiency values of $78 \%$ and $48 \%$ for TP and $\mathrm{Cr}$, respectively. However, concentrations of TKN and B were not statistically reduced at either HRTs. Regarding the absorption capacity of $P$. australis, the highest absorption efficiencies for TKN and TP were reported at 7 days in the aerial part of the plants. In contrast, B was retained in roots at HRT of 3 days. Finally, $\mathrm{Cr}$ was more significantly absorbed at 3 days by P. australis. Moreover, the substrates also played important roles in the adsorption of nitrogen and boron. Therefore, CWs planted with $P$. australis could be used as an ecofriendly technique to the reduce pollution load of the wastewater from tannery industry, especially for $\mathrm{P}$ and $\mathrm{Cr}$, although in order to increase the removal efficiency of $\mathrm{B}$ and $\mathrm{N}$, the combination with other plant species and different retention times should be tested.
\end{abstract}

Keywords: constructed wetland; depuration process; hydraulic retention time; Phragmites australis; phytoextraction; pollutants; wastewater

\section{Introduction}

The use of water in industrial processes is an operational process that inevitably generates a huge amount of wastewater in many industrial sectors. Both industrial and municipal sources are increased at a similar pace by the pre-eminent economic growth. Water pollution has led to the build-up of environmental contaminants and the consequent deterioration and pollution of water quality [1]. In fact, 
nowadays a large proportion of freshwater bodies have been contaminated and have to be regulated across the globe [2], with the protection of the environment being a major concern worldwide [3]. Additionally, the agricultural sector is the productive sector that consumes the most water in the world, using more than $70 \%$ of global water resources, mainly through farmland irrigation [4]. During the last decades, freshwater demand and shortages have both increased, with this situation being aggravated by the lack of or improper treatment of industrial wastewaters, creating risks such as food production reduction, industrial expansion obstruction, and difficulties related to both environmental and human health [5]. Water contamination and scarcity are phenomena that have increased all over the world and are two of the biggest challenges that humankind faces today. Therefore, innovative, ecofriendly, inexpensive solutions should be implemented, where the treatment and reuse of wastewater must have a prominent place [6].

Tanneries represent an industrial sector with a high environmental impact. Air and water pollution have been associated with tannery operations [2,7]. Among the main environmental damages are eutrophication, caused by enrichment of nutrients, especially phosphorous $(\mathrm{P})$ and nitrogen $(\mathrm{N})$, which reduce oxygen in the water body through intense bacterial mineralization and cause a risk to the aquatic ecosystem [8]. Moreover, leather tanning uses large quantities of chromium (Cr), which can leak into aquatic environments, such as rivers and lagoons, causing water pollution at local scales [9]. Additionally, boron (B) is present at high concentrations in tannery wastewater, the effluents in which could cause phytotoxicity in crop plants if they are used for irrigation purposes [10]. Therefore, wastewater from the tanning industry must be treated adequately due to the high amount of contaminating chemicals and biological residues created its production process. Wastewater treatment has evolved because of water deficits, which have increased pressure and concern regarding the search for new resources capable of reaching a balance between supply and demand [11].

There has been much interest in several treatment techniques for tannery wastewater [12], among which the use of constructed wetland $(\mathrm{CW})$ is a potential natural technology. CW technology is used worldwide for the treatment of wastewater from different sources, such as domestic, agricultural, industrial, mining, and water sources, and is able to reduce pollutants in wastewater and purify it $[13,14]$. CWs are engineered wetlands designed to simulate physical, chemical, and biological processes that occur in natural wetland, and they are able to treat wastewater [15]. Plants and substrate are the elements that have the most influence on system efficiency $[16,17]$. Substrates used to construct wetlands include soil, sand, gravel, rock, and organic materials such as compost, all of which are important for several reasons: (a) they support many of the living organisms in wetlands; (b) they provide storage for many contaminants; (c) chemical and biological transformations take place within the substrates; and (d) the accumulation of organic matter in the substrate provides sites for adsorption of pollutants and biological reactions in wetlands.

The use of plant species in CWs is highly recommended and numerous studies have demonstrated that vegetation plays an important role in pollutant removal in wetlands [18]. CWs create binding sites for biofilm, uptake nutrients, adsorb pollutants, are considered thermal isolates, release oxygen inside the substrates, and have an aesthetic function [19]. The plant species selection process is a key factor, since the vegetation has to survive the potential toxic effects of wastewater and its chemical variability, and of course it must be adapted to local climate conditions. Among the potential plants used in CWs, Phragmites australis (P. australis), the common reed, is a macrophyte that can phytoextracts and accumulate pollutants in its tissues via phytoaccumulation. It is used throughout the world for the treatment of industrial wastewaters in CWs [20]. Vymazal and Březinová [21] reported that P. australis is able to create conditions suitable for removal of pollutants, and also indicated that the role of plants is not limited to the uptake of nutrients and heavy metals, but that they also stimulate microorganism growth, increasing the purification system's efficiency.

In addition, CWs do not consume energy in their operation, since they use a combination of plants, microorganisms, and substrates, taking advantage of processes occurring in nature but within a more 
controlled environment $[14,21,22]$. This classifies them as lower level systems with lower operational and maintenance requirements [23].

The main objective of this study was to evaluate the ability of constructed wetland operating system to reduce pollutants in wastewater from the tannery industry, quantifying the efficiencies of depuration of the system, considering the absorption capacities of $P$. australis and various substrates. We also investigated the possible reuse of irrigation water according to the current legislation.

\section{Materials and Methods}

\subsection{Description of the Pilot Treatment System}

An integrated purification system utilizing a horizontal subsurface flow constructed wetland (HSSFCW) method working in parallel and in batch mode was implemented in Lorca, Murcia Region, southeast Spain ( $37^{\circ} 41^{\prime} 54^{\prime \prime}$ N, $1^{\circ} 43^{\prime} 19^{\prime \prime}$ W) (Figure 1). The wastewater from the tannery industry used in this study was collected after prepurification in an industrial wastewater treatment station, where physicochemical and biological treatments are carried out. The constructed wetland consisted of three cells measuring $27 \mathrm{~m}$ in length by $2.5 \mathrm{~m}$ in width, with a horizontal subsurface flow and with a cross-sectional slope of $1 \%$; the depth of the wetland was maintained at $1 \mathrm{~m}$. Each cell contained 80 $\mathrm{cm}$ of coarse gravel from limestone rocks in its bottom (diameter $23-40 \mathrm{~cm}$ ), consisting of hydrated carbonates, alkali and alkaline earth metals, and $20 \mathrm{~cm}$ of washed sand in the surface layer (patent ES 2 363363 B2). P. australis (Cav.) was planted as a phytoextractor species at a plant density of 10 per $\mathrm{m}^{2}$ (Figure 1). P. australis was planted two months prior to the start of the experiment in the HSSFCW, using irrigation water to promote its adaptation and development.

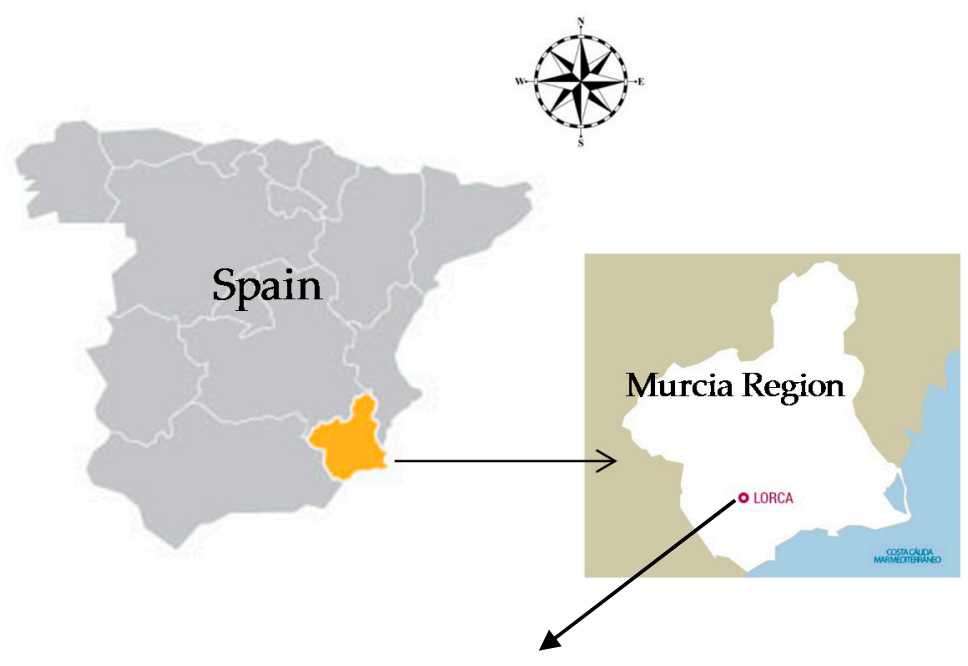

Figure 1. Cont. 
(a) Wastewa ter from Industrial Wastewa ter Treatment Station
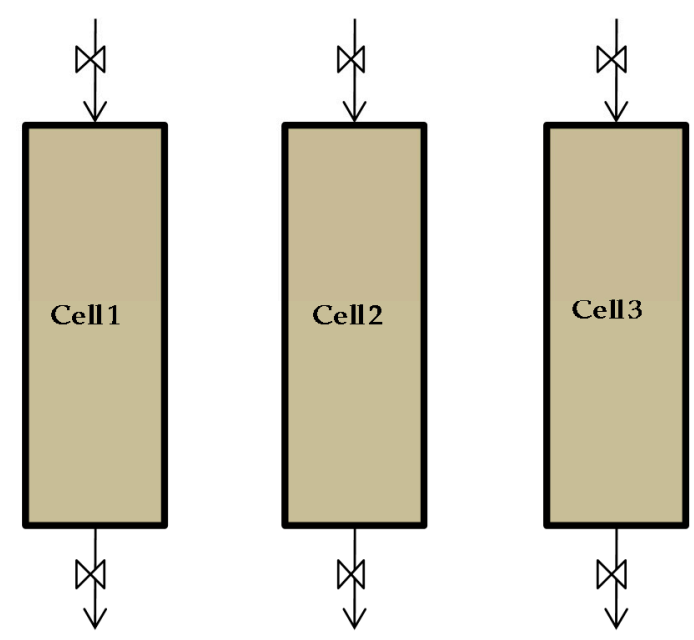

Treated water with cons tructed we tland (b)

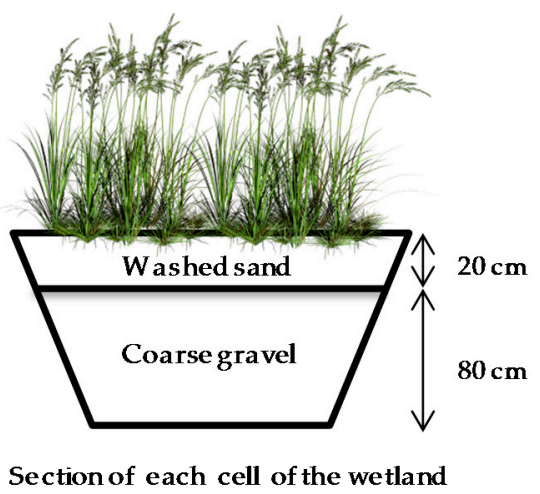

(c)

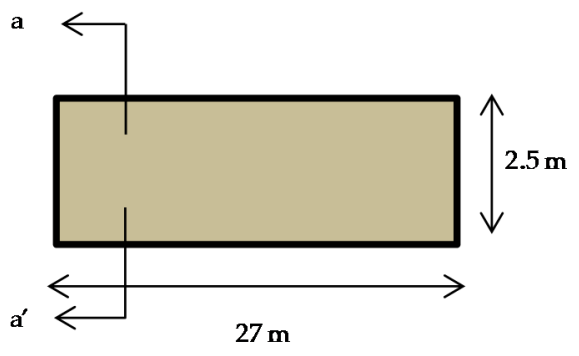

Plan view of each cell of the wetland

Figure 1. Study location and treatment system of constructed wetland: (a) three cells working in parallel; (b) sectional view of each cell of the wetland and composition; (c) plan view of each cell of the wetland.

\subsection{Wetland Management and Sampling Strategy}

The system was operated at two hydraulic retention times (HRT $\mathrm{S}_{\mathrm{s}}=3$ and 7 days), both of which were tested in 3 cycles of filling and emptying in the three cells of the HSSFCW. Three wastewater samples were collected at the inlet of each cell during the filling process (control samples), while the other three water samples were collected at the outlet of each cell when they were emptied. The first hydraulic retention time experiment was HRT $=3$ days. For the first cycle, the HSSFCW (across three cells) was filled on day 1 and emptied on day 3 . For the second cycle, the HSSFCW was again filled on day 3 (after emptying the first cycle) and emptied again on day 6. For the third cycle, we filled the HSSFCW again on day 6 and emptied the cells on day 9. After finishing the HRT $=3$ experiment, we used irrigation water before starting the HRT $=7$ experiment to clean the cells. Then, we followed the same process for HRT $=7$ as for HRT $=3$. A total of 30 days operation was carried out in the wetland, with cleaning carried out in the middle. This highlights that the system was not saturated during the period of the experiments. However, if the working time of the wetland was prolonged, evaluation of wetland saturation would have been carried out.

Taking into account the three cycles of treatment per HRT and the three replicates, the total number of samples per treatment was 27 samples at the inlet and 27 samples at the outlet. Therefore, a total of 54 samples for each HRT were collected (Table 1). Every sample was placed in $500 \mathrm{~mL}$ sterilized plastic bottles, labeled, and immediately cooled at $4{ }^{\circ} \mathrm{C}$ until analysis. 
Table 1. Sampling strategy for wastewater. Samples collected for both hydraulic retention times (HRTs).

\begin{tabular}{|c|c|c|c|c|c|c|c|c|c|c|c|c|}
\hline & \multicolumn{6}{|c|}{ HRT $=3$ days } & \multicolumn{6}{|c|}{ HRT $=7$ days } \\
\hline & \multicolumn{3}{|c|}{$\mathrm{I}_{3}$ (Control) } & \multicolumn{3}{|c|}{$\mathrm{O}_{3}$} & \multicolumn{3}{|c|}{$\mathrm{I}_{7}$ (Control) } & \multicolumn{3}{|c|}{$\mathrm{O}_{7}$} \\
\hline & $\begin{array}{c}\text { Cell } \\
1\end{array}$ & $\begin{array}{c}\text { Cell } \\
2\end{array}$ & $\begin{array}{c}\text { Cell } \\
3\end{array}$ & $\begin{array}{c}\text { Cell } \\
1\end{array}$ & $\begin{array}{c}\text { Cell } \\
2\end{array}$ & Cell 3 & Cell 1 & Cell 2 & Cell 3 & Cell 1 & Cell 2 & Cell 3 \\
\hline I Cycle & 3 & 3 & 3 & 3 & 3 & 3 & 3 & 3 & 3 & 3 & 3 & 3 \\
\hline II Cycle & 3 & 3 & 3 & 3 & 3 & 3 & 3 & 3 & 3 & 3 & 3 & 3 \\
\hline III Cycle & 3 & 3 & 3 & 3 & 3 & 3 & 3 & 3 & 3 & 3 & 3 & 3 \\
\hline TOTAL & & 27 & & & 27 & & & 27 & & & 27 & \\
\hline
\end{tabular}

$\mathrm{I}_{3}$ : wastewater samples at the inlet of the constructed wetland $(\mathrm{CW})$ for $\mathrm{HRT}=3 ; \mathrm{O}_{3}$ : water samples at the outlet of the $\mathrm{CW}$ for $\mathrm{HRT}=3$; $\mathrm{I}_{7}$ : wastewater samples at the inlet of the $\mathrm{CW}$ for $\mathrm{HRT}=7, \mathrm{O}_{7}$ : water samples at the outlet of the $\mathrm{CW}$ for $\mathrm{HRT}=7$.

Three P. australis plants were sampled from each cell before starting the cycles, which were used as controls. The aerial and root parts were separated in the laboratory and analyzed. After finishing the treatments for both HRTs ( 3 and 7 days), three samples of P. australis were collected in each cell, totaling 9 samples for each HRT. Therefore, a total of 27 P. australis plants were transported to the laboratory and analyzed. All of the sampled plants had the same size and volume. In order to decide which of the plants were to be sampled (all of them looked healthy and free of diseases and pests), a perceptual analysis of the all plantations was carried out. This analysis included evaluation of the color, shape, dimensions, and features of this species. We also carried out a detailed visual analysis of the aerial and root parts of the collected plants.

In addition, during the month of the experimental trial, no P. australis debris was found on the surface of the wetland. The wetland was checked twice a week and any part of the plant that fell onto the wetland was immediately removed. Additionally, any plant that died during the experiment was removed. Because the period of the experiments was short at only 30 days, it was not necessary to harvest the aerial part of $P$. australis, however if the wetland was operated for a longer time, the plants would have been harvest when the absorption capacity of the plant decreased, which should be checked through plant analysis.

Finally, three substrate samples of washed sand and gravel were taken prior to starting the treatment and two months after the $P$. australis plants were planted. These samples were used as control for both treatments (HRT $=3$ and 7 days). The washed sand was taken at a depth of $10 \mathrm{~cm}$ and gravel was collected at $60 \mathrm{~cm}$ depth. After each treatment, three samples were collected in each cell following the same strategy. Therefore, a total of 21 washed sand samples and 21 gravel samples were collected and analyzed.

\subsection{Analytical Methods}

Wastewater samples were analyzed following the APHA-AWWA methodology [24]. In brief, $\mathrm{pH}$ was determined using GLP21-CRISON and electrical conductivity (EC) was determined using GLP31-CRISON. Total nitrogen (TKN) was determined by Kjeldahl's method [25]. Total phosphorus (TP) was photometrically determined with molybdenum blue after acidic hydrolysis and oxidation at $120^{\circ} \mathrm{C}$ (Macherey-Nagel GmbH and Co., KG nanocolor test, reference 985 055). Boron (B) and chromium $(\mathrm{Cr})$ were determined after acid digestion using an inductively coupled plasma mass spectrometer (ICP-MS model Agilent 7500a).

Plant samples were washed with deionized water and dried for $48 \mathrm{~h}$ at $45^{\circ} \mathrm{C}$. A split of each sample was ground using an agate mortar (RestschRM 100). Total nitrogen was determined by Kjeldahl's method [25], which was modified using $0.15 \mathrm{~g}$ of dried sample in the digestion. Total phosphorus was photometrically determined with molybdenum blue after acidic hydrolysis and oxidation at $120^{\circ} \mathrm{C}$ (Macherey-Nagel GmbH and Co., KG nanocolor test, reference 985 055). The concentrations of $\mathrm{B}$ and $\mathrm{Cr}$ were determined by an inductively coupled plasma mass spectrometer (ICP-MS model Agilent 7500a). 
The substrate sample, containing washed sand and gravel, was washed in the laboratory and then both materials were dried and ground. Total nitrogen was determined by Kjeldahl's method [25] and TP tests following the test for $\mathrm{NaHCO}_{3}$ [26]. For B and Cr, digestion was carried out following testing of the soils for toxic metals [27]. These were measured using an inductively coupled plasma mass spectrometer (ICP-MS model Agilent 7500a).

\subsection{Data Analysis}

Microsoft Excel program was used to perform descriptive statistical analysis of the data. In addition, in order to identify significant differences in the chemical compositions of the inlet and outlet wastewaters at 3 and 7 days, one-way analysis of variance (ANOVA) was performed followed by post-hoc Tukey's test [28] at $p<0.05$. The same test was used to identify statistical differences between concentrations of studied elements in aerial and root parts of P. australis at 3 and 7 days of HRT, as well as in the capacity of adsorption of these elements in washed sand and gravel at 3 and 7 days of HRTs.

\section{Results}

\subsection{Wastewater Characterization at the Inlet and Outlet of the Wetland}

Table 2 shows $\mathrm{pH}, \mathrm{EC}, \mathrm{TKN}, \mathrm{TP}, \mathrm{B}$, and $\mathrm{Cr}$ concentrations in wastewater samples collected at the inlet and outlet of the wetland at hydraulic retention times of 3 and 7 days. The table also includes the removal efficiencies calculated for all previous parameters.

Table 2. Chemical composition of wastewater at the inlet and outlet of the $\mathrm{CW}$, and removal efficiencies for HRTs of 3 and 7 days.

\begin{tabular}{|c|c|c|c|c|c|c|c|}
\hline Parameters & $\mathbf{I}_{3}$ & $\mathrm{O}_{3}$ & $\mathbf{I}_{7}$ & $\mathrm{O}_{7}$ & $\begin{array}{c}\text { Removal } \\
\text { Efficiency } \\
(\%)\end{array}$ & $\begin{array}{l}\text { Removal } \\
\text { Efficiency } 7 \\
(\%)\end{array}$ & $p$-Values \\
\hline $\mathrm{pH}$ & $7.9 \pm 0.1 b$ & $7.4 \pm 0.0 \mathrm{a}$ & $7.2 \pm 0.2 \mathrm{a}$ & $7.4 \pm 0.1 \mathrm{a}$ & - & - & 0.030 \\
\hline $\mathrm{EC}\left(\mathrm{dS} \mathrm{m}^{-1}\right)$ & $13.7 \pm 0.9 b$ & $11.6 \pm 1.3 \mathrm{ab}$ & $11.0 \pm 0.4 \mathrm{a}$ & $11.6 \pm 0.4 \mathrm{ab}$ & 15.3 & -5.6 & 0.019 \\
\hline $\mathrm{TKN}\left(\mathrm{mg} \mathrm{L}^{-1}\right)$ & $816 \pm 12 b$ & $737 \pm 39 b$ & $510 \pm 60 a$ & $503 \pm 27 a$ & 9.6 & 1.4 & 0.821 \\
\hline $\mathrm{TP}\left(\mathrm{mg} \mathrm{L}^{-1}\right)$ & $7.7 \pm 6.8 c$ & $1.7 \pm 1.6 \mathrm{a}$ & $4.5 \pm 2.6 \mathrm{~b}$ & $1.7 \pm 0.1 \mathrm{a}$ & 77.7 & 66.4 & 0.015 \\
\hline $\mathrm{B}\left(\mathrm{mg} \mathrm{L}^{-1}\right)$ & $4.5 \pm 0.7$ & $3.9 \pm 0.3$ & $4.5 \pm 1.6$ & $4.0 \pm 1.0$ & 13.4 & 10.8 & 0.230 \\
\hline $\mathrm{Cr}\left(\mathrm{mg} \mathrm{L}^{-1}\right)$ & $0.23 \pm 0.0 \mathrm{~b}$ & $0.12 \pm 0.0 \mathrm{a}$ & $0.36 \pm 0.1 \mathrm{c}$ & $0.22 \pm 0.1 b$ & 47.8 & 38.9 & 0.000 \\
\hline
\end{tabular}

$\mathrm{I}_{3}$ : water at the inlet of the $\mathrm{CW}$ for $\mathrm{HRT}=3, \mathrm{O}_{3}$ : water at the outlet of the $\mathrm{CW}$ for $\mathrm{HRT}=3$; $\mathrm{I}_{7}$ : water at the inlet of the $\mathrm{CW}$ for $\mathrm{HRT}=7, \mathrm{O}_{7}$ : water at the outlet of the $\mathrm{CW}$ for $\mathrm{HRT}=7$; efficiency 3 : removal efficiency for $\mathrm{HRT}=3$; efficiency 7 : removal efficiency for $\operatorname{HRT}=7$. Different letters $(a, b, c)$ in the same row indicate statistically significant differences $(p<0.05)$ among means of each parameter. $\mathrm{EC}=$ electrical conductivity; TKN $=$ total nitrogen; TP $=$ total phosphorous; $\mathrm{B}=$ boron; $\mathrm{Cr}=$ chromium.

Mean $\mathrm{pH}$ values at the inlet and outlet for HRT $=3$ were 7.9 and 7.4, respectively, showing statistically significant differences. In contrast, for $\mathrm{HRT}=7$, similar $\mathrm{pH}$ values were registered, showing 7.2 at the inlet and 7.4 at the outlet. The electrical conductivity of the wastewater ranged from 11 to $13.7 \mathrm{dS} \mathrm{m}^{-1}$ and statistically significant differences were not observed between the inlet and outlet for either of the HRTs.

Mean TKN concentrations at the inlet and outlet for HRT $=3$ days were $816 \mathrm{mg} \mathrm{L}^{-1}$ and $737 \mathrm{mg} \mathrm{L}^{-1}$, respectively; while for HRT $=7$ days, these concentrations were $510 \mathrm{mg} \mathrm{L}^{-1}$ and $503 \mathrm{mg} \mathrm{L}^{-1}$, respectively. Significant differences $(p \leq 0.05)$ were not observed. In contrast, TP and $\mathrm{Cr}$ concentrations were statistically different in the inlet and outlet when the wastewater was retained for 3 and 7 days in the CWs. Mean B concentration at the inlet for HRT $=3$ and HRT $=7$ was $4.5 \mathrm{mg} \mathrm{L}^{-1}$, while at the outlet for both HRTs the values were $3.9 \mathrm{mg} \mathrm{L}^{-1}$ and $4.0 \mathrm{mg} \mathrm{L}^{-1}$, respectively. Therefore, no statistically significant differences were reported.

The highest removal efficiencies were registered for $\mathrm{P}$ and $\mathrm{Cr}$, at $77 \%$ and $48 \%$ for $\mathrm{HRT}=3$, respectively; and $66 \%$ and $39 \%$ for $\mathrm{HRT}=7$, respectively (Table 2 ). 
The treated wastewater can be applied in agricultural soils according to Royal Decree 1620/2007 if the concentrations of the chemical parameters established in this legislation are achieved, for example $0.5 \mathrm{mg} \mathrm{L}^{-1}$ and $0.1 \mathrm{mg} \mathrm{L}^{-1}$ for $\mathrm{B}$ and $\mathrm{Cr}$, respectively, and an EC value lower than $3.0 \mathrm{dS} \mathrm{m}^{-1}$. The rest of the analyzed parameters are not referenced in this legislation.

\subsection{Absorption Capacity by Phragmites Australis}

Total nitrogen concentrations in P. australis before the start of the treatments (control) were $809 \pm 96 \mathrm{mg} \mathrm{kg}^{-1}$ in the aerial part and $762 \pm 99 \mathrm{mg} \mathrm{kg}^{-1}$ in the root part (Figure 2). However, when wastewater was treated in the wetland for 3 days, the aerial part showed a statistically significant increment compared to the control. In contrast, no differences were observed for the roots, with concentrations of up to $2091 \pm 81 \mathrm{mg} \mathrm{kg}^{-1}$ and $1312 \pm 98 \mathrm{mg} \mathrm{kg}^{-1}$ for TKN in the samples and controls, respectively. Contrarily, the concentrations of TKN in aerial and root parts for HRT $=7$ were statically higher than those reported in the control samples, with values of $2516 \pm 91$ and $1756 \pm 82 \mathrm{mg} \mathrm{kg}^{-1}$ in the samples and controls, respectively. Finally, for both HRTs, statistically significant differences were reported between aerial and root parts.
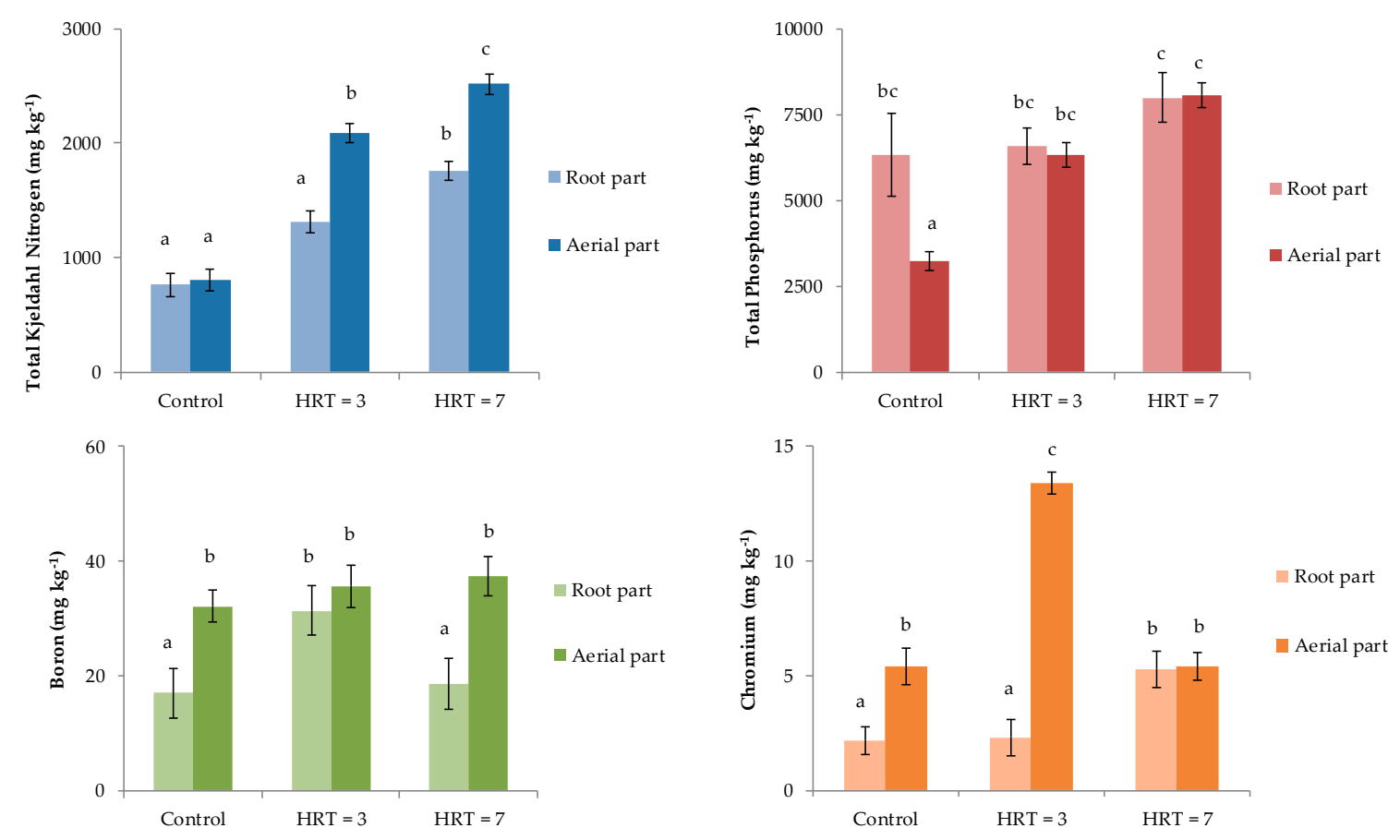

Figure 2. Concentrations of TKN, TP, B, and $\mathrm{Cr}$ in aerial part and roots of P. australis.

Total phosphorous concentrations found for HRT $=3$ days were $6323 \pm 367 \mathrm{mg} \mathrm{kg}^{-1}$ in the aerial part and $6574 \pm 524 \mathrm{mg} \mathrm{kg}^{-1}$ in the root part, with no statically significant differences among them. Similarly, for HRT $=7$ days, no significant differences were observed, the concentrations of which were $8062 \pm 361$ and $7993 \pm 725 \mathrm{mg} \mathrm{kg}^{-1}$ in aerial and root parts, respectively. Finally, TP concentrations in roots from control and both HRTs were statistically similar, while concentrations in the aerial part for both HRTs were statistically higher than the concentrations reported in the control samples.

Boron concentrations in plants collected at HRT $=3$ days were statistically similar in the aerial and root parts at $35.7 \pm 3.7 \mathrm{mg} \mathrm{kg}^{-1}$ and $31.4 \pm 4.4 \mathrm{mg} \mathrm{kg}^{-1}$, respectively. In contrast, for HRT = 7, B concentrations in aerial and root parts were $37.4 \pm 3.5$ and $18.6 \pm 4.4 \mathrm{mg} \mathrm{kg}^{-1}$, respectively, showing significant differences. Only roots at HRT $=3$ days showed B concentrations that were statistically higher than control samples.

Finally, Cr concentrations in the control plants were $5.4 \pm 0.8$ and $2.2 \pm 0.6 \mathrm{mg} \mathrm{kg}^{-1}$ in aerial and root parts, respectively. Otherwise, $\mathrm{Cr}$ concentrations found in both aerial and root parts for 
$\mathrm{HRT}=7$ were statistically similar, at around $5.4 \mathrm{mg} \mathrm{kg}^{-1}$ (Figure 2). In contrast, for $\mathrm{HRT}=3$, there were significant differences among the $\mathrm{Cr}$ concentrations obtained in the two parts of the plant that were analyzed, with values of $13.4 \pm 0.5 \mathrm{mg} \mathrm{kg}^{-1}$ in the aerial part and $2.3 \pm 0.5 \mathrm{mg} \mathrm{kg}^{-1}$ in the roots.

\subsection{Substrate Influence}

Mean concentrations of TKN were $217 \pm 6 \mathrm{mg} \mathrm{kg}^{-1}$ in gravel and $323 \pm 12 \mathrm{mg} \mathrm{kg}^{-1}$ in washed sand in samples collected before the start of the wastewater treatment (control samples), in which significant differences were found (Figure 3). For HRT $=3$ days, no significant difference in TKN concentrations was found between gravel and washed sand, whose values were $331 \pm 5 \mathrm{mg} \mathrm{kg}^{-1}$ and $319 \pm 29 \mathrm{mg} \mathrm{kg}^{-1}$, respectively. Similarly, at HRT $=7$ days, gravel and washed sand adsorbed similar concentration of nitrogen at $213 \pm 11 \mathrm{mg} \mathrm{kg}^{-1}$ and $219 \pm 27 \mathrm{mg} \mathrm{kg}^{-1}$, respectively. The only significant differences were reported between TKN concentration in gravel for HRT of 3 days compared to control samples.

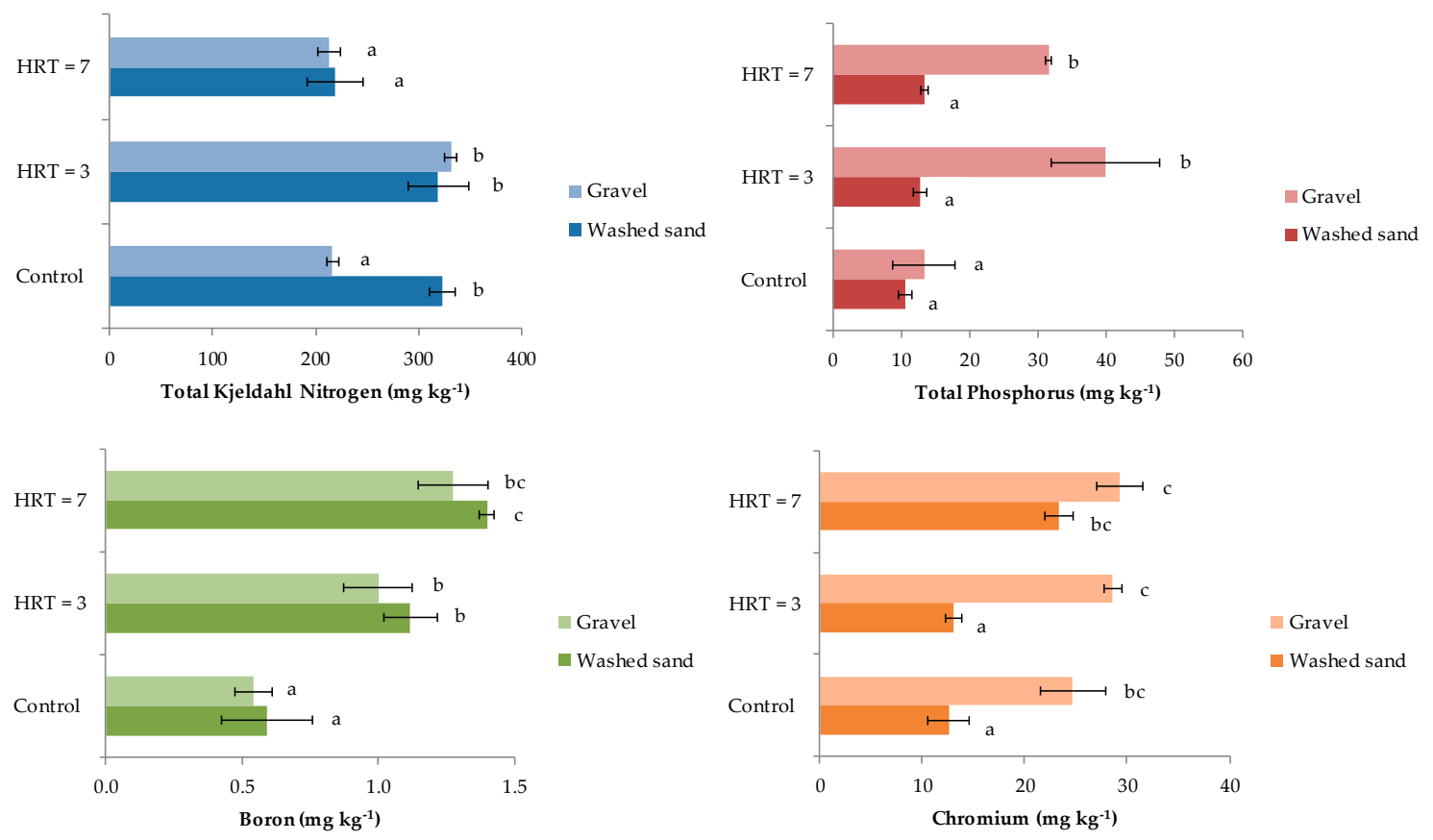

Figure 3. TKN, TP, B and Cr adsorption by the substrate.

Total phosphorous concentrations showed significant differences between gravel and washed sand when wastewater was treated with both HRTs, the concentrations of which after 3 days were $40 \pm 8 \mathrm{mg} \mathrm{kg}^{-1}$ and $13 \pm 1 \mathrm{mg} \mathrm{kg}^{-1}$, respectively; and at 7 days were $32 \pm 1 \mathrm{mg} \mathrm{kg}^{-1}$ and $14 \pm 1 \mathrm{mg} \mathrm{kg}^{-1}$, respectively. The TP concentrations were significantly higher in gravel for both HRTs compared to the control.

In the case of $\mathrm{B}$, the maximum concentrations were found for HRT $=7$ days, with $1.3 \pm 0.3 \mathrm{mg} \mathrm{kg}^{-1}$ ingravel and $1.4 \pm 0.2 \mathrm{mg} \mathrm{kg}^{-1}$ in washed sand. No significant differences $(p \leq 0.05)$ were found between both materials. For HRT $=3$ days, the B concentrations were around $1.0 \pm 0.1 \mathrm{mg} \mathrm{kg}^{-1}$ for both gravel and washed sand, which were significantly higher than concentrations determined in control samples of $0.5 \pm 0.1 \mathrm{mg} \mathrm{kg}^{-1}$ and $0.6 \pm 0.2 \mathrm{mg} \mathrm{kg}^{-1}$ for gravel and washed sand, respectively.

According to the results (Figure 3), for HRT $=3$, gravel adsorbed $29 \pm 1 \mathrm{mg} \mathrm{kg}^{-1}$, while washed sand absorbed $13 \pm 1 \mathrm{mg} \mathrm{kg}^{-1}$, showing statistical differences (Figure 3). In contrast, the longest retention time (7 days) allowed similar $\mathrm{Cr}$ adsorption values for the gravel and washed sand of $29 \pm 2 \mathrm{mg} \mathrm{kg}^{-1}$ and $23 \pm 1 \mathrm{mg} \mathrm{kg}^{-1}$, respectively. The only statistically significant increase in $\mathrm{Cr}$ adsorption was reported for washed sand at HRT $=7$ when compared to the control. 


\section{Discussion}

\subsection{Decreased Eutrophication Risk caused by the Constructed Wetland}

Nitrogen and phosphorous are essential elements for living systems [29]. However, their discharge from anthropogenic sources has been identified as a principal pollution problem in aquatic media resulting in water eutrophication [30]. Quantifiable indicators of eutrophication include an increase of opportunistic primary producers, which increase turbidity; decreased oxygen present in the water; and high levels of nitrogen [31]. Therefore, water eutrophication can cause environmental, ecosystem, social, and economic problems [32], and should be avoided.

According to the results for nitrogen concentrations in inlet and outlet wastewater for both HRTs, no statistically significant reduction occurred in the studied wetlands (Table 2). However, TKN concentration is not limited according to Royal Decree 1620/2007. Therefore, the treated water can be used in agriculture. Other studies carried out at HRT $=7$ days for pig slurry treatment reported a TN remove efficiency of around 30\% [33]. Calheiros et al. [34] also treated tannery wastewater in CWs planted with Sarcocornia fruticosa and Arundo donax, reporting efficiency values of over $75 \%$ for HRT = 2 days. In this study, the main removal mechanisms were plant uptake and other processes, such as sedimentation or ammonia volatilization [35,36]. However, according to Vymazal [36], the volatilization of $\mathrm{NH}_{3}$ is insignificant at $\mathrm{pH}$ levels below 7.5, and is possibly not relevant at pH levels below 8.0. In contrast, at $\mathrm{pH} 9.3$ the ratio between ammonia and ammonium ions in wastewater is 1:1 and the loss via volatilization is significant. Table 2 shows that the water at the inlet of the CW for HRT $=3$ had a $\mathrm{pH}$ 7.9. Therefore, slight ammonia volatilization could have occurred.

Nevertheless, the highest concentrations of nitrogen in P. australis (aerial and roots tissues) were reported after 7 days of treatment, due to the higher development of $P$. australis biomass and increase of microbiological activity promoted by root development. Liu et al. [37] indicated that P. australis was the most important component of CWs, because this species directly absorbed nitrogen from wastewater and improved the microenvironment in the substrate beds for the development of microorganisms.

The nitrogen adsorption by the substrates did significantly increase, except for gravel at HRT $=3$ days (Figure 3). This could be due to the adsorption of ammonium on gravel surfaces. In addition, a surface layer of biofilm on the surfaces of gravel was observed, which transforms ammonia into nitrite or nitrate when in contact with wastewater and dissolved oxygen [38].

Therefore, the main mechanisms involved in nitrogen removal in this study were absorption by $P$. australis and adsorption by the gravel layer, although a nitrification-denitrification process may have also taken place [18]. In fact, the process of nitrification-denitrification can occur in CWs when oxygen leakage from the rhizosphere is united with atmospheric oxygen favoring nitrification, while anaerobic conditions present in the CW bed favor the denitrification process [33]. However, this process has little effect because there is a limited volume of reduced sediment in the studied CWs, which decrease the potential for removal by denitrification [33]

According to the results for phosphorous, P. australis achieved the highest absorption at HRT = 7 days in both roots and aerial parts of the plants. Physical and chemical processes and biological factors are involved when wastewater is retained for a longer time in wetlands [39]. In addition, the presence of polyphosphorous-accumulating bacteria (PAO) in the biofilm, which use soluble phosphorous as a substrate, could be an implicated mechanism [39] and could improve P removal in the system.

However, two important mechanisms for elimination of $\mathrm{P}$ in wetlands are $\mathrm{P}$ adsorption in the substrate (Figure 3) and chemical precipitation of P with calcium, iron, aluminum, or organic matter [26]. Zhuang et al. [38] indicated that P coprecipitaiton with aragonite or adsorption on colloidal particles could also occur in CWs. In addition, some research studies have pointed out the capacity of gravel in CWs for P adsorption [40], being one of the main mechanisms investigated in this study. The best removal efficiency for TP was in gravel, owing to the high adsorption ability of this substrate for salt particles [24]. The highest concentration of TP in the form of phosphates was found in the treated wastewater. Additionally, in the gravel composition, limestone promotes the precipitation of Ca 
phosphates [18], increasing the system efficiency. Typically, gravel can remove between $25 \%$ and $60 \%$ of P [41]. Moreover, CWs enriched with hemp biochar substrate to treat domestic wastewater achieved mean P removal efficiencies of $94.3 \%$ [42]. Similarly, P removal was greatly enhanced, exceeding $90 \%$ when the HRT was longer than $4 \mathrm{~h}$ in electrolysis-integrated CWs [43] and achieving a removal rate of $61 \%$ in tannery wastewater using cupola slag media in CWs [23]. Efficiency values close to $80 \%$ in this research were achieved via different mechanisms, such as substrate adsorption, chemical precipitation, microbial action (mainly by poly-P bacteria), and plant uptake [44], reducing the eutrophication risk and reducing $\mathrm{P}$ concentrations.

\subsection{Contamination Risk from Toxic Elements}

In tannery processes, high chemical and heavy metal concentrations are used, which are the main causes of pollution in wastewater, generating effluents with large quantities of toxic elements [45]. The presence of boron in water can negatively affect human health, causing infertility and problems during pregnancy, or even affecting the health of plants and animals [46]. Therefore, boron is classified as a moderate to highly toxic element in aquatic environments [47]. In addition, $30 \%-40 \%$ of the chromium salts used in the tannery industry are found in wastewater [48], and therefore this industry is considered as a major source of potential water pollution, producing wastewater that can cause major environmental concerns [49].

Several research studies have shown that wetlands have considerable potential to remove $\mathrm{B}$ from wastewater, demonstrating that plants and substrates have strong ability for B removal from wastewater [50]. Additionally, it is important to note that the mass removal rate achieved by CWs is mostly related to sorption of B in filtration media, B accumulation or precipitation in organic-based media, and plant uptake [51]. The system tested in this study demonstrated the accumulation of B in the substrates and especially in vegetation, as evidenced by the results obtained. This accumulation of B into the plant, especially in the roots, might be achieved by some efflux transporter proteins that enable B to be pumped into cells [52]. However, filtration in wetlands has been shown to be an important process in the removal of B from wastewater [53]. Additionally, the sorption mechanism in organic-based materials has been identified as a key factor of boron removal [54].

Many studies have shown that $B$ retention is mainly caused by the action of organic-based media and sand. For example, Ali and Choudhury [55] reported that $60 \%$ of B was stored in a filtration medium composed of a mixture of organic-based peat and sand. In contrast, the system used in this study demonstrated that plants had an important role in B adsorption, although total efficiencies found were lower than those obtained in other studies. One study used Typha latifolia as a phytoextractor species, where $64 \%$ of B was retained [51]. Another study used Lemna minor and Lemna gibba, which accumulated more than $1000 \mathrm{mg} \mathrm{B} \mathrm{kg}^{-1}$ in the tissues [56]. Therefore, although the system used reduced the $B$ concentration in wastewater, and therefore minimized toxic elements and purified the water, the system should be improved by using new filtration media and incorporating others plant species to maximize B removal and reach the concentration thresholds recommended by Royal Decree $1620 / 2007$ for the reuse of water in agricultural irrigation.

Regarding chromium, Zhang et al. [57] reported that planted wetlands have a considerable effect on water purification because they are able to accumulate heavy metals. It is generally agreed that the major functions of plants in CWs are to create suitable conditions for removal of pollutants, even though sometimes the direct role of plants is limited to uptake of nutrients and heavy metals. Calheiros et al. [58] indicated that metals are mainly retained in the belowground biomass of plants, but in this study $\mathrm{Cr}$ was accumulated mainly in aerial parts of plants at HRT $=3$ days. This was because the translocation factor (TF) in P. australis at this HRT was elevated [56,57], which is an effective phytoremediation process [58]. However, the TF was lower at HRT $=7$ days, likely due to the saturation of this metal in shoots and leaves [59], which accumulated in the roots thought precipitation of $\mathrm{Cr}$ ions (especially $\mathrm{Cr}$ III), with carboxylic compounds in the cell walls of plant tissues preventing translocation [60]. 
Although the results showed that $P$. australis has a high capacity to absorb $\mathrm{Cr}$, there is a lack of knowledge about root absorption capacity and the processes involved in translocation to aboveground biomass [21]. In addition to metal sorption in planted constructed wetlands, the cell wall capsules and slime layers contain polysaccharides that allow ionic exchange with certain metals, as well as with proteins and lipids whose functional groups (e.g., amino, carboxylic, sulfhydryl, and phosphate groups) are capable of binding with metals [60]. The higher physical adsorption due to higher amounts of functional groups as binding sites at the cell surface would explain the higher efficiency at HRT $=$ 3 days.

The substrates in CWs also made physicochemical and biological processes that occurred through interactions in the rhizosphere possible [61] and improved the efficiencies obtained. Nevertheless, the best efficiency was found at HRT $=3$ days, possibly due to the joint action of the formation of insoluble sulfides in anaerobic conditions within the sediment, which allow divalent metal cation removal in constructed wetlands [13]. Additionally, other mechanism such as complexation, microprecipitation, or saturation of binding sites may be involved in Cr removal [62].

Research studies carried out with CWs treating Cr-bearing wastewater showed efficiencies of 98\% when planted with cattail, while unplanted CWs showed a removal efficiency of 95\% [61]. Mant et al. [63] constructed four wetland systems to treat tannery effluents, including a control system without plants and three experimental systems that were planted with one of three species: Penisetum purpureum, Brachiaria decumbens, or Phragmites australis. The percentage removal efficiency values for chromium after $1 \mathrm{~h}$ were $78 \%$ (P. purpureum), 68.5\% (B. decumbens), 56.7\% (P. australis), and $47.2 \%$ (control). In addition, CWs composed of river gravel and granitic rock were efficient in removing chromium, with $57 \%-83 \%$ and $67 \%-77 \%$ efficiencies, respectively [64]. Although the efficiencies obtained for $\mathrm{Cr}$ (Table 2) were lower than those reported in the mentioned studies, they were sufficient to reduce this toxic element to concentrations below the threshold values established in the legislation for reuse of treated water for agricultural irrigation (Royal Decree 1620/2007) at HRT $=3$ day.

\section{Conclusions}

The results of this study showed that the optimal retention time for wastewater treatment in this wetland for removal of $\mathrm{P}$ and $\mathrm{Cr}$ was after 3 days, however after 7 days $\mathrm{P}$ and $\mathrm{Cr}$ were also removed. In contrast, concentrations of $\mathrm{N}$ and $\mathrm{B}$ were not reduced at either HRTs.

P. australis showed greater capacity to absorb $\mathrm{N}$ and $\mathrm{P}$ in aerial parts of the plants at $\mathrm{HRT}=3$ days, while $B$ was retained in roots at HRT $=3$ days, and $\mathrm{Cr}$ was more significantly absorbed after 3 days by $P$. australis. These results suggest that $P$. australis is a good phytoextractor species, which combined with constructed wetlands may considerably reduce the pollution load of the wastewater. Moreover, the substrates also played important roles in the adsorption of nitrogen and boron. However, in order to conclude which specific processes are involved in the removal of each studied element, further research should be carried out.

Therefore, this treatment system using aquatic macrophytes in CWs presents a low cost and very adequate alternative for treating industrial effluents. It is appropriate for reducing some elements from tannery industrial wastewater, and for reducing the concentrations of pollutants to below threshold values for some parameters established by Royal Decree 1620/2007 for potential reuse of treated water as irrigation water. Moreover, planted CWs minimize the eutrophication risk by decreasing $\mathrm{P}$ concentrations in wastewater, in turn decreasing the risk of pollution of groundwater and freshwater, since decreasing $\mathrm{Cr}$ concentration improves water quality.

Although the results were good, in order to increase the removal efficiency of nitrogen and boron, new species of macrophytes should be tested. These plants should present higher aerial biomass and higher root surface characteristics in order to favor shading and the formation of an extensive area suited for retaining and adsorbing nutrients. Moreover, new substrates could be tested to improve filtration media. A carbon filter could be installed before CW experiments and a sand filter could be installed after CW experiments to obtain concentrations of pollutants below thresholds levels 
established by the legislation, and to allow reuse of industrial wastewater from tanneries in agriculture. Finally, although during this experiment we did not have any saturation problems in the wetland, in future research a life cycle and long term removal efficiency analyses should be carried out.

Author Contributions: Conceptualization A.G.-V. and M.Á.M.; methodology, M.A.T.; formal analysis, M.A.T.; investigation, A.G.-V.; writing-original draft preparation, A.G.-V.; writing—review and editing, J.A.A., S.M.-M., and M.D.G.-L.; supervision, J.A.A. and S.M.-M.; project administration, Á.F. and M.D.G.-L.; funding acquisition, Á.F. and M.Á.M. All authors have read and agreed to the published version of the manuscript.

Funding: This research was funded by AGUAS DE LORCA S.A. grant number 4497/16CTA.

Conflicts of Interest: The authors declare no conflict of interest. The funders had no role in the design of the study; in the collection, analyses, or interpretation of data; in the writing of the manuscript, or in the decision to publish the results".

\section{References}

1. Goh, P.S.; Ismail, A.F. A review on inorganic membranes for desalination and wastewater treatment. Desalination 2018, 434, 60-80. [CrossRef]

2. Raper, E.; Stephenson, T.; Anderson, D.R.; Fisher, R.; Soares, A. Industrial wastewater treatment through bioaugmentation. Process Saf. Environ. Prot. 2018, 118, 178-187. [CrossRef]

3. Crudu, M.; Deselnicu, V.; Deselnicu, D.C.; Albu, L. Valorization of titanium metal wastes as tanning agent used in leather industry. Waste Manag. 2014, 34, 1806-1814. [CrossRef] [PubMed]

4. Wang, F.; Yu, C.; Xiong, L.; Chang, Y. How can agricultural water use efficiency be promoted in China? A spatial-temporal analysis. Resour. Conserv. Recycl. 2019, 145, 411-418. [CrossRef]

5. Swain, A.K.; Sahoo, A.; Jena, H.M.; Patra, H. Industrial wastewater treatment by Aerobic Inverse Fluidized Bed Biofilm Reactors (AIFBBRs): A review. J. Water Process Eng. 2018, 23, 61-74. [CrossRef]

6. Ricart, S.; Rico, A.M. Assessing technical and social driving factors of water reuse in agriculture: A review on risks, regulation and the yuck factor. Agric. Water Manag. 2019, 217, 426-439. [CrossRef]

7. Nazer, D.W.; Al-Sa'Ed, R.M.; Siebel, M.A. Reducing the environmental impact of the unhairing-liming process in the leather tanning industry. J. Clean. Prod. 2006, 14, 65-74. [CrossRef]

8. Nguyen, T.T.N.; Némery, J.; Gratiot, N.; Strady, E.; Quoc, V.; Truong, A.; Aimé, J.; Peyne, A. Science of the Total Environment Nutrient dynamics and eutrophication assessment in the tropical river system of SaigonDongnai ( southern Vietnam ). Sci. Total Environ. 2019, 653, 370-383. [CrossRef]

9. Vignati, D.A.L.; Ferrari, B.J.D.; Roulier, J.; Coquery, M.; Szalinska, E.; Bobrowski, A.; Czaplicka, A. Science of the Total Environment Chromium bioavailability in aquatic systems impacted by tannery wastewaters. Part 1: Understanding chromium accumulation by indigenous chironomids. Sci. Total Environ. 2019, 653, 401-408. [CrossRef]

10. Can, O.; Yakar, A.; Gür, N. Bioaccumulation and toxicity assessment of irrigation water contaminated with boron ( B ) using duckweed ( Lemna gibba L.) in a batch reactor system. J. Hazard. Mater. 2017, 324, 151-159.

11. Salgot, M.; Folch, M.; Unit, S.S.; Goh, P.S.; Ismail, A.F.; Raper, E.; Stephenson, T.; Anderson, D.R.; Fisher, R.; Soares, A. A review on inorganic membranes for desalination and wastewater treatment. Process Saf. Environ. Prot. 2018, 118, 178-187.

12. Gerek, E.E.; Y1lmaz, S.; Koparal, A.S.; Gerek, N. Combined energy and removal efficiency of electrochemical wastewater treatment for leather industry. J. Water Process Eng. 2019, 30, 100382. [CrossRef]

13. Gill, L.W.; Ring, P.; Casey, B.; Higgins, N.M.P.; Johnston, P.M. Long term heavy metal removal by a constructed wetland treating rainfall runoff from a motorway. Sci. Total Environ. 2017, 601-602, 32-44. [CrossRef] [PubMed]

14. Di Luca, G.A.; Maine, M.A.; Mufarrege, M.M.; Hadad, H.R.; Pedro, M.C.; Sánchez, G.C.; Caffaratti, S.E. Phosphorus distribution pattern in sediments of natural and constructed wetlands. Ecol. Eng. 2017, 108, 227-233. [CrossRef]

15. Bakhshoodeh, R.; Alavi, N.; Paydary, P. Composting plant leachate treatment by a pilot-scale, three-stage, horizontal flow constructed wetland in central Iran. Environ. Sci. Pollut. Res. 2017, 24, 23803-23814. [CrossRef] [PubMed] 
16. Kizito, S.; Lv, T.; Wu, S.; Ajmal, Z.; Luo, H.; Dong, R. Treatment of anaerobic digested effluent in biochar-packed vertical flow constructed wetland columns: Role of media and tidal operation. Sci. Total Environ. 2017, 592, 197-205. [CrossRef]

17. Lu, S.; Zhang, X.; Wang, J.; Pei, L. Impacts of different media on constructed wetlands for rural household sewage treatment. J. Clean. Prod. 2016, 127, 325-330. [CrossRef]

18. Caballero-Lajarín, A.; Zornoza, R.; Faz, A.; Lobera, J.B.; Muñoz, M.A.; Domínguez-Oliver, S.G. Combination of Low-Cost Technologies for Pig Slurry Purification under Semiarid Mediterranean Conditions. Water. Air. Soil Pollut. 2015, 226, 341. [CrossRef]

19. Saggaï, M.M.; Ainouche, A.; Nelson, M.; Cattin, F.; El Amrani, A. Long-term investigation of constructed wetland wastewater treatment and reuse: Selection of adapted plant species for metaremediation. J. Environ. Manag. 2017, 201, 120-128. [CrossRef]

20. Mulkeen, C.J.; Williams, C.D.; Gormally, M.J.; Healy, M.G. Seasonal patterns of metals and nutrients in Phragmites australis (Cav.) Trin. ex Steudel in a constructed wetland in the west of Ireland. Ecol. Eng. 2017, 107, 192-197. [CrossRef]

21. Vymazal, J.; Březinová, T. Accumulation of heavy metals in aboveground biomass of Phragmites australis in horizontal flow constructed wetlands for wastewater treatment: A review. Chem. Eng. J. 2016, 290, $232-242$. [CrossRef]

22. Irwin, N.B.; Irwin, E.G.; Martin, J.F.; Aracena, P. Constructed wetlands for water quality improvements: Benefit transfer analysis from Ohio. J. Environ. Manag. 2018, 206, 1063-1071. [CrossRef] [PubMed]

23. Saeed, T.; Afrin, R.; Al Muyeed, A.; Sun, G. Treatment of tannery wastewater in a pilot-scale hybrid constructed wetland system in Bangladesh. Chemosphere 2012, 88, 1065-1073. [CrossRef] [PubMed]

24. APHA; AWWA. Standard Methods for Examination of Water and Wastewater; 22nd American Public Health Association: Washington, DC, USA, 2012.

25. Duchaufour, P. Council Directive of 12 December 1991. 1970.

26. Watanabe, F.S.; Olsen, S.R. Test of Ascorbic Acid Method for Determining Phosphorous in Water and NaHCO3 Extracts from Soil; Soil Science Society of America Proceedings: Madison, WI, USA, 1965.

27. Risser, J.A.; Baker, D.E. Testing Soils for Toxic Metals; Westerman, R.L., Ed.; Soil Sciences Society of America Spec. Publ: Madison, WI, USA, 1990.

28. Lavrnić, S.; Alagna, V.; Iovino, M.; Anconelli, S.; Solimando, D.; Toscano, A. Hydrological and hydraulic behaviour of a surface flow constructed wetland treating agricultural drainage water in northern Italy. Sci. Total Environ. 2020, 702, 134795. [CrossRef] [PubMed]

29. Huang, J.; Xu, C.; Ridoutt, B.G.; Wang, X.; Ren, P. An Nitrogen and phosphorus losses and eutrophication potential associated with fertilizer application to cropland in China. J. Clean. Prod. 2017, 159, 171-179. [CrossRef]

30. McIver, R.; Cullain, N.; Schmidt, A.L.; Lotze, H.K. Linking eutrophication indicators in eelgrass habitats to nitrogen loading and mitigating site characteristics in eastern New Brunswick, Canada. Mar. Environ. Res. 2019, 144, 141-153. [CrossRef]

31. Cosme, N.; Jones, M.C.; Cheung, W.W.L.; Larsen, H.F. Spatial differentiation of marine eutrophication damage indicators based on species density. Ecol. Indic. 2017, 73, 676-685. [CrossRef]

32. Zhang, W.; Jin, X.; Liu, D.; Lang, C.; Shan, B. Temporal and spatial variation of nitrogen and phosphorus and eutrophication assessment for a typical arid river - Fuyang River in northern China. J. Environ. Sci. (China) 2017, 55, 41-48. [CrossRef]

33. Muñoz, M.A.; Rosales, R.M.; Gabarrón, M.; Faz, A.; Acosta, J.A. Effects of the Hydraulic Retention Time on Pig Slurry Purification by Constructed Wetlands and Stabilization Ponds. Water. Air. Soil Pollut. 2016, 227, 293. [CrossRef]

34. Calheiros, C.S.C.; Quitério, P.V.B.; Silva, G.; Crispim, L.F.C.; Brix, H.; Moura, S.C.; Castro, P.M.L. Use of constructed wetland systems with Arundo and Sarcocornia for polishing high salinity tannery wastewater. $J$. Environ. Manag. 2012, 95, 66-71. [CrossRef]

35. Steidl, J.; Kalettka, T.; Bauwe, A. Nitrogen retention efficiency of a surface-flow constructed wetland receiving tile drainage water: A case study from north-eastern Germany. Agric. Ecosyst. Environ. 2019, 283, 106577. [CrossRef]

36. Vymazal, J. Removal of nutrients in various types of constructed wetlands. Sci. Total Environ. 2007, 380, 48-65. [CrossRef] [PubMed] 
37. Liu, X.; Zhang, Y.; Li, X.; Fu, C.; Shi, T.; Yan, P. Effects of influent nitrogen loads on nitrogen and COD removal in horizontal subsurface flow constructed wetlands during different growth periods of Phragmites australis. Sci. Total Environ. 2018, 635, 1360-1366. [CrossRef] [PubMed]

38. Zhuang, L.-L.; Yang, T.; Zhang, J.; Li, X. The configuration, purification effect and mechanism of intensified constructed wetland for wastewater treatment from the aspect of nitrogen removal: A review. Bioresour. Technol. 2019, 293, 122086. [CrossRef] [PubMed]

39. Sehar, S.; Sumera; Naeem, S.; Perveen, I.; Ali, N.; Ahmed, S. A comparative study of macrophytes influence on wastewater treatment through subsurface flow hybrid constructed wetland. Ecol. Eng. 2014, 81, 62-69. [CrossRef]

40. Healy, M.G.; O' Flynn, C.J. The performance of constructed wetlands treating primary, secondary and dairy soiled water in Ireland (a review). J. Environ. Manag. 2011, 92, 2348-2354. [CrossRef]

41. Vymazal, J. Removal of phosphorus in constructed wetlands with horizontal sub-surface flow in the Czech Republic. Water Air Soil Pollut. Focus 2004, 4, 657-670. [CrossRef]

42. Bolton, L.; Joseph, S.; Greenway, M.; Donne, S.; Munroe, P.; Marjo, C.E. Phosphorus adsorption onto an enriched biochar substrate in constructed wetlands treating wastewater. Ecol. Eng. X 2019, 1, 100005. [CrossRef]

43. Gao, Y.; Xie, Y.W.; Zhang, Q.; Wang, A.L.; Yu, Y.X.; Yang, L.Y. Intensified nitrate and phosphorus removal in an electrolysis -integrated horizontal subsurface-flow constructed wetland. Water Res. 2017, 108, 39-45. [CrossRef]

44. Liang, Y.; Zhu, H.; Bañuelos, G.; Yan, B.; Zhou, Q.; Yu, X.; Cheng, X. Constructed wetlands for saline wastewater treatment: A review. Ecol. Eng. 2017, 98, 275-285. [CrossRef]

45. Mohammed, K.; Sahu, O. Recovery of chromium from tannery industry waste water by membrane separation technology: Health and engineering aspects. Sci. African 2019, 4, e00096. [CrossRef]

46. Babiker, E.; Al-Ghouti, M.A.; Zouari, N.; McKay, G. Removal of boron from water using adsorbents derived from waste tire rubber. J. Environ. Chem. Eng. 2019, 7, 102948. [CrossRef]

47. Venturi, S.; Vaselli, O.; Tassi, F.; Nisi, B.; Pennisi, M.; Cabassi, J.; Bicocchi, G.; Rossato, L. Geochemical and isotopic evidences for a severe anthropogenic boron contamination: A case study from Castelluccio (Arezzo, central Italy). Appl. Geochemistry 2015, 63, 146-157. [CrossRef]

48. Zou, D.; Chi, Y.; Dong, J.; Fu, C.; Wang, F.; Ni, M. Supercritical water oxidation of tannery sludge: Stabilization of chromium and destruction of organics. Chemosphere 2013, 93, 1413-1418. [CrossRef] [PubMed]

49. Kokkinos, E.; Proskynitopoulou, V.; Zouboulis, A. Chromium and energy recovery from tannery wastewater treatment waste: Investigation of major mechanisms in the framework of circular economy. J. Environ. Chem. Eng. 2019, 7, 103307. [CrossRef]

50. Yıldırım, K.; Kasım, G.Ç. Phytoremediation potential of poplar and willow species in small scale constructed wetland for boron removal. Chemosphere 2018, 194, 722-736. [CrossRef] [PubMed]

51. Türker, O.C.; Türe, C.; Böcük, H.; Çiçek, A.; Yakar, A. Role of plants and vegetation structure on boron (B) removal process in constructed wetlands. Ecol. Eng. 2016, 88, 143-152. [CrossRef]

52. Zhu, H.; Bañuelos, G. Evaluation of two hybrid poplar clones as constructed wetland plant species for treating saline water high in boron and selenium, or waters only high in boron. J. Hazard. Mater. 2017, 333, 319-328. [CrossRef]

53. Lizama Allende, K.; Fletcher, T.D.; Sun, G. The effect of substrate media on the removal of arsenic, boron and iron from an acidic wastewater in planted column reactors. Chem. Eng. J. 2012, 179, 119-130. [CrossRef]

54. Ye, Z.H.; Lin, Z.Q.; Whiting, S.N.; De Souza, M.P.; Terry, N. Possible use of constructed wetland to remove selenocyanate, arsenic, and boron from electric utility wastewater. Chemosphere 2003, 52, 1571-1579. [CrossRef]

55. Türker, O.C.; Yakar, A. A hybrid constructed wetland combined with microbial fuel cell for boron (B) removal and bioelectric production. Ecol. Eng. 2017, 102, 411-421. [CrossRef]

56. Türker, O.C.; Vymazal, J.; Türe, C. Constructed wetlands for boron removal: A review. Ecol. Eng. 2014, 64, 350-359. [CrossRef]

57. Zhang, S.; Bai, J.; Wang, W.; Huang, L.; Zhang, G.; Wang, D. Heavy metal contents and transfer capacities of Phragmites australis and Suaeda salsa in the Yellow River Delta, China. Phys. Chem. Earth 2018, 104, 3-8. [CrossRef] 
58. Calheiros, C.S.C.; Rangel, A.O.S.S.; Castro, P.M.L. Evaluation of different substrates to support the growth of Typha latifolia in constructed wetlands treating tannery wastewater over long-term operation. Bioresour. Technol. 2008, 99, 6866-6877. [CrossRef] [PubMed]

59. Kamal, A.K.I.; Islam, M.R.; Hassan, M.; Ahmed, F.; Rahman, M.A.T.M.T.; Moniruzzaman, M. Bioaccumulation of Trace Metals in Selected Plants within Amin Bazar Landfill Site, Dhaka, Bangladesh. Environ. Process. 2016, 3, 179-194. [CrossRef]

60. Sultana, M.Y.; Akratos, C.S.; Pavlou, S.; Vayenas, D.V. Chromium removal in constructed wetlands: A review. Int. Biodeterior. Biodegrad. 2014, 96, 181-190. [CrossRef]

61. Papaevangelou, V.A.; Gikas, G.D.; Tsihrintzis, V.A. Chromium removal from wastewater using HSF and VF pilot-scale constructed wetlands: Overall performance, and fate and distribution of this element within the wetland environment. Chemosphere 2017, 168, 716-730. [CrossRef]

62. Mandal, T.; Dasgupta, D.; Mandal, S.; Datta, S. Treatment of leather industry wastewater by aerobic biological and Fenton oxidation process. J. Hazard. Mater. 2010, 180, 204-211. [CrossRef]

63. Mant, C.; Costa, S.; Williams, J.; Tambourgi, E. Phytoremediation of chromium by model constructed wetland. Bioresour. Technol. 2006, 97, 1767-1772. [CrossRef]

64. Dotro, G.; Castro, S.; Tujchneider, O.; Piovano, N.; Paris, M.; Faggi, A.; Palazolo, P.; Larsen, D.; Fitch, M. Performance of pilot-scale constructed wetlands for secondary treatment of chromium-bearing tannery wastewaters. J. Hazard. Mater. 2012, 239-240, 142-151. [CrossRef]

(C) 2020 by the authors. Licensee MDPI, Basel, Switzerland. This article is an open access article distributed under the terms and conditions of the Creative Commons Attribution (CC BY) license (http://creativecommons.org/licenses/by/4.0/). 